ANDRIUS SPRINDZIUNAS

Institute of Humanities Mykolas Romeris University

Vilnius, Lithuania

\title{
PRINCIPAL GROUNDS OF CATHOLIC AND OTHER RELIGIONS IN RECENT LEGAL PROCEEDINGS IN LITHUANIA
}

There haven't been numerous cases related with religion in the practice of Lithuanian courts during the recent decades. Still several latest cases could be discussed as specific examples. In 2010 the European Court of Human Rights announced a judgement in the case of Gineitiene v. Lithuania ${ }^{1}$. The Applicant Ms. Gineitiene alleged that former decision of Lithuanian court to place her two daughters with their father had been in breach of Articles 8, 9 and 14 of the Convention for the Protection of Human Rights and Fundamental Freedoms, in particular referring to the right to respect of private and family life, freedom of thought, conscience and religion, and prohibition of discrimination. The brief story before the act was the applicant becoming involved in the activities of the Ojas Meditation Center, a Lithuanian branch of a new religious movement called Osho. Then a year later the applicant divorced her husband and after some period her husband requested that his home be fixed as the place of residence of their two daughters. One of his allegations was that applicant's involvement in the Osho religious movement could have a negative influence on the children. Kaunas District Court decided that one of the daughters should reside with the mother

\footnotetext{
${ }^{1}$ Case of Gineitienè v. Lithuania. Application no. 20739/05. Judgement. European Court of Human Rights, Strasbourg, 27 July 2010.
} 
and the other with the father, but after few years the court amended the decision and fixed the place of residence of both daughters with their father. Then the mother submitted a cassation appeal, arguing that the true reason for taking away her daughters was her membership of the Osho religious movement, then after some period she appealed to the European Court of Human Rights (ECHR).

The ECHR analyzed the case and recognized, that Lithuanian courts have made a thorough analysis of the best interests of the children. Turning to the applicant's claim that the Lithuanian courts discriminated against her on the basis of her religious beliefs the Court rejected it, stating that the primary concern of the domestic courts was the children's best interests. Recognizing that in a couple of paragraphs of the judgements the domestic courts did touch upon the applicant's religious affiliation, the ECHR stated that that text was an isolated reference and was unrelated to the applicant's ability to bring up her children. ${ }^{2}$

One of the latest cases related with religion in Lithuania was started after complaints of people about visual advertisements of a clothing line headed by Mr. Robertas Kalinkinas. The campaign featured three visual advertisements which were displayed on twenty advertising hoardings in public areas in Vilnius and on Robertas Kalinkinas' website ${ }^{3}$. All three of them looked like Christian icons. The first of the three advertisements showed a young man with long hair, a headband, a halo around his head and several tattoos wearing a pair of jeans. A caption at the bottom of the image read "Jesus, what a jeans!" in English version and "Jesus, what are your trousers!" literally in Lithuanian. Another advertisement showed a young woman wearing a white dress and a headdress with white and red flowers on it. She had a halo around her head and was holding a string of beads, looking like a rosary. The caption at the bottom of the image read "Mother of god, what a dress!" in English version and "Dear Mary, what a dress!" in Lithuanian version.

\footnotetext{
${ }^{2}$ Ibid, $\$ 36-\$ 40$.

${ }^{3}$ www.robertkalinkin.com
} 
The third advertisement showed the same man and woman together, composed like a pieta. The man was reclining and the woman was standing next to him with one hand placed on his head and the other on his shoulder. The caption at the bottom of the image read "Jesus, Mary! What a style!" in English and "Jesus [and] Mary, what are you wearing?"4 literally in Lithuanian. After around one hundred of complaints were received by Lithuanian Bishops Conference, the State Consumer Rights Protection Authority (SCRPA) and other institutions, public and legal debates started. One of the complaints stated that the advertisements degraded religious symbols, offended the feelings of religious people and created "a danger that society might lose the necessary sense of sacredness and basic respect for spirituality" and asked the SCRPA to fine the applicant company and to order it to remove the advertisements as being contrary to public order and public morals. Lithuanian Advertising Agency noted, that "religious people always react very sensitively to any use of religious symbols or religious personalities in advertising... in this case it has gone too far. Humor is understandable but it can really offend religious people. We suggest other characters for communicating the uniqueness of the product" 6 . Then State Inspectorate of Non-Food Products informed the designer that the advertisements were possibly in violation of the Law on Advertising as being contrary to public morals. The designer's company submitted written explanations to the Inspectorate stating that in the advertisements the word "Jesus" was used not as an address of a religious personality but as an emotional interjection. Because of its common use to express one's emotions, the word has lost its exclusively religious significance. While people depicted in the advertisements could not be unambiguously

\footnotetext{
${ }^{4}$ The advertisements were possibly no longer visible in the R.K.'s original website but were still viewable in many other websites by key words „Kalinkin summer collection 2013“, also in many other internet publications, for instance, http://www. fashionbloc.co.uk/2018/02/06/robert-kalinkin-jesus-jeans/

${ }^{5}$ Case of Sekmadienis Ltd. v. Lithuania. Application no. 69317/14. Judgement. European Court of Human Rights, Strasbourg, 30 January 2018. $\$ 12$.

${ }^{6}$ Ibid, $\$ 13$.
} 
considered religious persons, but even if they were, that depiction was aesthetical and not disrespectful, unlike various kitschy religious items typically sold in markets. Answering to public reproach, the designer and his representatives argued that the people depicted in the advertisements differed from the depiction of Jesus and Mary in religious art, and that an educated and cosmopolitan society would not equate every picture with such art. They said that they had relied on a wordplay in the advertisements and they had been meant to be funny but not to offend anyone ${ }^{7}$.

Lithuanian Bishops Conference noted that "the advertisements ... make both visual and written references to religious sacred objects, such as a rosary, the names of Jesus and Mary, and the symbol of Pieta... Christ and Mary, as symbols of faith, represent certain moral values and embody ethical perfection... the persons of Christ and Mary are thereby degraded as symbols of the sacredness of the Christian faith. For that reason, such depiction offends the feelings of religious people. The degrading and distortion of religious symbols by purposely changing their meaning is contrary to public morals, especially when is done in pursuit of commercial gain, and must therefore not be allowed, in line with Article 4 of the Law on Advertising", stipulating that advertising shall be banned if it violates public morals, or degrades human honour and dignity, or incites religious hatred, etc. It's important to note, that in the process of the mentioned scandal the Article was amended by adding a sub-paragraph banning an advertisement if "it expresses contempt for religious symbols of religious communities registered in Lithuania."

Consequently, the SCRPA considered that "the elements of the advertisements taken together - the persons, symbols and their positioning - would create an impression for the average consumer that the depicted persons and objects were related to religious symbols" and because of multiple complaints, proving that the feelings of religious

\footnotetext{
${ }^{7}$ Ibid, $\$ 14$.

${ }^{8}$ Law on Advertising. Republic of Lithuania, 1 August 2013.

${ }^{9}$ Law on Advertising. Republic of Lithuania, 1 August 2013. Article $4 \$ 2$.
} 
people have been offended, "it must be emphasized that respect for religion is undoubtedly a moral value. Accordingly, disrespecting religion breaches public morals." ${ }^{10}$ The designer's company was given a fine of 2000 Lithuanian litai (LTL). When determining the penalty, it took into account several circumstances: the advertisements had been displayed in public places and must have reached a wide audience, including location in the proximity of Cathedral and there had been complaints about them; at the same time, the advertisements had only been displayed for a few weeks and only in the city of Vilnius; the applicant company had stopped displaying them after it had been warned by the authorities, and it had cooperated with the SCRPA; it had been the first such violation committed by the applicant company. Therefore, the designer's company had been given a fine which had been close to the minimum provided in law.

Yet the designer's company did not agree with the decision and appealed to Vilnius Regional Administrative Court and later to the Supreme Administrative Court of Republic of Lithuania. Alongside with his earlier arguments of justification, the applicant submitted that the advertisements were a product of artistic activity and were therefore protected freedom of expression, guaranteed by the Constitution Republic of Lithuania and European Convention for the Protection of Human Rights and Fundamental Freedoms (Article 10, Freedom of Expression) $)^{11}$.

Domestic courts dismissed designer's applications and later Lithuanian Government was lodged with the European Court of Human Rights. Explaining earlier decisions of Lithuanian courts, the representative of the Lithuanian Government did not dispute that there had been an interference with the applicant company's right to freedom of expression, but they submitted that that interference

\footnotetext{
${ }^{10}$ Case of Sekmadienis Ltd. v. Lithuania. Application no. 69317/14. Judgement. European Court of Human Rights, Strasbourg, 30 January 2018. $\$ 18$.

${ }^{11}$ European Convention on Human Rights. European Court of Human Rights, Council of Europe. www.echr.coe.int
} 
had been justified under Article $10 \$ 2$ of the Convention ${ }^{12}$, stipulating that the exercise of freedoms also carries with its duties and responsibilities and may be subject to such formalities, conditions, restrictions or penalties as are prescribed by law and are necessary in a democratic society, in the interests of national security, territorial integrity or public safety, for the prevention of disorder or crime, for the protection of health or morals, for the protection of the reputation or rights of others, etc. The representative submitted that the concept of "public morals" was necessarily broad and its contents could change over time, so it was impossible to provide a precise definition of public morals in law. Thus, the main argument was based on the relation between religion and morality, emphasizing the historic importance of Christianity in Lithuania and the number of Christians among the population. Yet these arguments were not appreciated by ECHR and a conclusion was made stating that Lithuanian domestic authorities failed to balance between protection of public morals and the rights of religious people on the one hand, and the designer's company's right to freedom of expression on the other hand. They concluded, that Lithuanian "authorities gave absolute primacy to protecting the feelings of religious people, without adequately taking into account the applicant company's right to freedom of expression"13.

Another even more harsh case of using Christian symbols followed in Facebook advertisements of a barbecue restaurant named "Keule ruke" ("A pig was smoking") in Vilnius. Their advertisements depicted a smiling crucified man, a prayer book swamped with catchup and extracted pages lying by a hamburger, written text saying "Lord, I see", mentioning heaven, pig's Christmas and Easter. SCRPA fined the restaurant for breaching the Article $4 \$ 2$ of the Law on Advertising for expression of contempt for religious symbols and trespassing the limits of freedom of expression. Owners of the restaurant applied to Vilnius Regional Administrational Court and got the fine

\footnotetext{
12 Ibid.

${ }^{13}$ Case of Sekmadienis Ltd. v. Lithuania. Application no. 69317/14 European Court of Human Rights, Strasbourg, 30 January 2018. \$ 77-83.
} 
diminished, as one of six their advertisements was recognized as not offensive. In a similar way as it was in the case of Mr. Kalinkinas, the owners of the restaurant argued that they did not meant to scorn the crucifix, that the resemblance of their smiling crucified man to Jesus Christ was casual and negotiable, they mean it to be funny, but not offensive.

The presented cases invoked a discussion on what are the substantial grounds of Lithuanian laws and judicial practice when the issues of religion are involved.

There have been more incidents involving issues of religion and public morals which lead to small administrative punishments or were not registered at all. Some of them were cases of sneering and ridiculing people who were practicing their religion, for instance, foreign tourists making faces and pointing fingers at people praying in the church of St.Theresa and Ostra Brama chapel, one harsh accident when a tourist from Holland demonstrated his naked body parts to a group of people together with a priest praying rosary in front of Vilnius Cathedral, some incidents of disturbing religious ceremonies, some acts of vandalism and some acts with symptoms of blasphemy, but Lithuanian laws do not qualify blasphemy as a crime.

It was evident that Lithuanian officials have put their efforts to defend Catholic values and traditional Christian point of view, preventing use of religious symbols for commercial purpose. In the case of Mr. Kalinkinas domestic courts appealed to the only suitable paragraph at that time forbidding to violate public morals. Detailed study of the arguments of Lithuanian judges and other officials revealed their awareness of deep intrinsic relationship between Christian culture and public morals in Lithuania, but it was not enough for the judges of ECHR and some Lithuanian intellectuals. What is morality and what is the content of the public morality in multicultural democratic country? There can be not a definite and functional answer for lawyers. In fact, judges of the ECHR stated an unqualified indictment by Lithuanian courts in the case of Mr. Kalinkinas questioning rights to freedom of expression of presumable 
minority groups in Lithuanian society. It's important to note, that a judge from Malta Vincent A. De Gaetano in his concurring opinion in that case wrote: "In the instant case, however, there was nothing in the three adverts in question (which, incidentally, can still be viewed online) which could, by any stretch of the imagination, be considered as either offensive, much less as amounting to any form of vilification of religion or religious symbols ... The fact that the head of the male figure bore some resemblance to the way in which the image of Christ is depicted in classical art, and the use of the words "Jesus" and "Mary" ... cannot conceivably, by or of themselves, or in combination, be regarded as violating "public morals"”14.

While popular media presented a simplified version of the discussed case, interpreting it as a mere attempt of domestic courts of Lithuania to restrict freedom of expression ${ }^{15}$, some Lithuanian lawyers indicated a much more serious issue. Vygantas Malinauskas took a note of ECHR concluding that R.K.'s advertisements "at the outset they do not appear to be gratuitously offensive or profane, nor do they incite hatred on the grounds of religious belief or attack a religion in an unwarranted or abusive manner"16 but missing to consider the universal principles of human dignity, when images of Jesus and Mary were used for the commercial purpose and evidently interfered with Christian ethos ${ }^{17}$.

\footnotetext{
${ }^{14}$ Concurring Opinnion of Judge De Gaetano // Case of Sekmadienis Ltd. v. Lithuania. Application no. 69317/14 European Court of Human Rights, Strasbourg, 30 January 2018. P. 30.

${ }^{15}$ For instance, a publication in British Fashion Bloc named „Lithuania tried to ban Jesus from wearing jeans“ at http://www.fashionbloc.co.uk/2018/02/06/robert-kalinkin-jesus-jeans/ or „Can Jesus Wear Jeans? Strasbourg Court Will Decide“ at https:// www.liberties.eu/en/news/lithuania-echr-freedom-of-expression-religion/9940.

${ }^{16}$ Case of Sekmadienis Ltd. V. Lithuania. Application no. 69317/14 European Court of Human Rights, Strasbourg, 30 January 2018. $\$ 77$.

${ }^{17}$ Vygantas Malinauskas. EŽTT bylos „UAB Sekmadienis prieš Lietuvą“ sprendimo probleminiai aspektai“ (The Problemic Aspects of the ECHR Case „Sekmadienis Ltd. v. Lithuania”) // Teisès apžvalga (Law Review) ISSN 2029-4239 (online). No. 1 (17), 2018, p. 133-136.
} 
Some more insights can be done to conclude and to explain the different positions of Lithuanian and ECHR judges. One of the reasons why arguments of Lithuanian judges were dismissed in Strasburg could be different mentality as it was conditioned by the post-soviet and free Western society experiences. In Soviet Lithuania normative public morality was emphasized and selfexplanatory. In the terms of sociology of values, it was rather orientation to norms and traditions. Meanwhile, that boundary has been crossed much earlier in the Western world, removing the morally binding elements of the "good", "traditional" and even "fair" from obligatory behavioral models. Normative imperative has been replaced with the human rights imperative, while the vector in the field of values was shifted towards the freedom of expression. It would explain the patronizing tone and a lightly sneering attitude of ECHR judges towards Lithuanian judges when explaining that while there is no carte blanche for desecration of religious symbols, official indictments ought to be formulated in a different manner.

KEY WORDS: religion; Christian symbols; public morals; freedom of expression; Lithuanian courts; European Court of Human Rights

\section{About The AUthor:}

ANDrius SPRindžıūnas Ph.D. - Associated Professor of the Mykolas Romeris University. Lecturer at the Institute of Humanities. Vilnius, Lithuania. 